\title{
Analysis of Needs For Using Android-Based KPSP Applications In Monitoring The Growth of Together
}

\author{
Indria Nuraini*, Isabella Hasiana, Nabila Sayangbati Gamas \\ Universitas PGRI Adi Buana, Indonesia \\ Corresponding author: indria@unipasby.ac.id
}

\begin{abstract}
Background: The development process occurs simultaneously with growth, so that every growth is accompanied by a change in function. Development is the result of the interaction of the maturity of the central nervous system with the organs it affects. The development of the early phase in the form of cognitive, motor, emotional, social, and language functional abilities, is a determinant of the development of the next phase. If there is a deficiency in one aspect of development, it can affect other aspects, so there is a need for early detection of toddler growth and development.

Purpose: This study aimed to find out the need for KPSP applications in monitoring the growth and development of toddlers.

Methods: This research uses a descriptive-analytic design, cross-sectional approach. The population of this study amounted to 36 respondents, with a purposive sampling technique. The research site is in the Surabaya area by distributing questionnaires in the form of Google Form. Analyze data with Descriptive Analysis.

Results: The results of this study stated that before the pandemic monitoring of toddler growth and development was carried out at the Posyandu using the KIA Handbook Instrument/Tool, while during the pandemic monitoring of toddler growth and development could not be carried out directly because of a policy. In this regard, respondents need an instrument/tool that can be used for independent monitoring of growth and development.

Conclusion: Monitoring the growth and development of toddlers during the pandemic by utilizing technological advances and being up to date.
\end{abstract}

Keywords: KPSP, Android, Growth and Development, Toddler. 


\section{Journal Of Nursing Practice}

http://thejnp.org

ISSN: 2614-3488 (print); 2614-3496 (online)

Vol.5 No.1. October 2021. Page.120-125

\section{BACKGROUND}

Creating a superior generation requires a long and continuous process. This stage begins in the first 1000 days of human life. The golden period of growth and development occurs at an early age, where growth and development occurs very rapidly and is holistic in various aspects ranging from cognitive, numeracy literacy, social-emotional and physical (Amanullah, 2018). During this pandemic, the government issued a regulation on LargeScale National Restrictions in the context of accelerating the handling of Covid 19, indirectly affecting basic health services for toddlers, one of which is monitoring growth and development services at Posyandu and making policies for monitoring growth and development independently at home with using the KIA Handbook (Kementerian Kesehatan Republik Indonesia, 2020). The impact of this policy on the growth of children under five is a decline based on age and growth stagnates, growth is based on height (Widiastuti \& Winarso, 2020). The results of the performance report of the Ministry of Health in 2020 there are $23.33 \%$ districts/cities that provide maternal and newborn health services, $11.76 \%$ districts/cities carry out active Posyandu development, and $46.9 \%$ districts/cities that achieve the target of $80 \%$ Immunization complete base (Kemenkes, 2021). The results of a survey from UNICEF, the impact of Covid 19 in Indonesia has experienced several impacts as a result of the pandemic, one of which is increasing malnutrition in toddlers (UNICEF, 2020). Health services are currently experiencing VUCA (Volatile, Uncertainty, Complexity, and Ambiguity) conditions due to disruption in health services (disruption in healthcare). Current medical technology can be telemedicine, virtual and augmented reality, mobile phones, and smartphones. Meanwhile, digital-based innovations in health services such as cloud computing, supercomputing, big data, Internet of things-IoT play an important role in health services (Kemenkes, 2021). The results in previous studies showed that monitoring the growth and development of Toddlers/Toddlers during the pandemic with a Mobile basis could help parents, Posyandu cadres, and Puskesmas in monitoring the growth and development of toddlers/toddlers in the Covid-19 pandemic conditions (Styawati \& Ariany, 2021). Other studies also explain that mobile-based health applications for monitoring early detection of growth and development of children aged 4-6 years (DDTK) are effective for the use (Wulandari \& Pangastuti, 2020). From several references that discuss the effectiveness of using Mobile in health services, the researchers hereby conduct a survey related to the need for using an Android-based KPSP application for monitoring the growth and development of toddlers that can be used by parents independently.

\section{OBJECTIVE}

The purpose of this study is to find out how important the need for an Android-based KPSP application is for monitoring the growth and development of toddlers.

\section{METHODS}

This research uses a descriptive-analytic design, cross-sectional approach. The population of this study was children aged 0-3 years totaling 36 respondents, with purposive sampling technique. Toddlers who were studied were taken who live in Surabaya by distributing questionnaires in the form of Google Form. Analyze data with Descriptive Analysis. 


\section{Journal Of Nursing Practice}

\section{RESULTS}

Table 1. Frequency Distribution of Toddler Age

\begin{tabular}{ccc}
\hline Toddler Age & Total & Percentase (\%) \\
\hline 0-1 years & 12 & 33,3 \\
$>1-2$ years & 12 & 33,3 \\
$>2-3$ years & 12 & 33,4 \\
\hline Total & $\mathbf{3 6}$ & $\mathbf{1 0 0}$ \\
\hline
\end{tabular}

Source: Primary Data, 2021

Based on table 1. Age of toddlers who are respondents $0-3$ years with a percentage of $33.3 \%$ each

Table 2. Frequency Distribution of Toddler Gender

\begin{tabular}{ccc}
\hline Gender & Total & Percentase (\%) \\
\hline Man & 15 & 41,7 \\
Woman & 21 & 58,3 \\
\hline Total & $\mathbf{3 6}$ & $\mathbf{1 0 0}$ \\
\hline
\end{tabular}

Source: Primary Data, 2021

In table 2. Most of the respondents are women with 21 children under five (58.3\%).

Table 3. Frequency Distribution of Growth Monitoring Sites

Toddler before the Pandemic

\begin{tabular}{ccc}
\hline Growth Monitoring Place & Total & Percentase (\%) \\
\hline Posyandu & 25 & 69,4 \\
Midwife & 7 & 19,4 \\
Puskesmas & 4 & 11,2 \\
\hline Total & $\mathbf{3 6}$ & $\mathbf{1 0 0}$ \\
\hline
\end{tabular}

Source: Primary Data, 2021

In Table 3. It is explained that the majority of children under five are monitored for growth and development at the Posyandu, as many as 25 toddlers $(69.4 \%)$.

Table 4. Frequency Distribution of Tools/Media for Monitoring Toddler Growth

\begin{tabular}{ccc}
\hline Growth Media/Tools & Total & Percentase (\%) \\
\hline Card Towards Health & 12 & 33,3 \\
Maternal and Child Health & 20 & 55,6 \\
Book & 4 & 11,1 \\
Midwife's explanation & 0 & 0 \\
\hline Cadre explanation & $\mathbf{3 6}$ & $\mathbf{1 0 0}$ \\
\hline Total & &
\end{tabular}

Source: Primary Data, 2021

Based on Table 4. Mothers of children under five will know the level of growth and development of their toddlers from the KIA book by 20 respondents $(55.6 \%)$. 
Table 5. Frequency Distribution of Mother Toddler Ability in Monitoring Growing Toddler Development independently

\begin{tabular}{ccc}
\hline Self-monitoring & Total & Percentase (\%) \\
\hline Independent & 12 & 33,3 \\
Not Independent & 24 & 66,7 \\
\hline Total & $\mathbf{3 6}$ & $\mathbf{1 0 0}$ \\
\hline
\end{tabular}

Source: Primary Data, 2021

In Table 5. Most of the respondents were unable to independently monitor the growth and development of toddlers by 24 respondents $(66.7 \%)$.

Table 6. Frequency Distribution of Application Needs Growing

\begin{tabular}{ccc}
\hline Application Needs & Total & Percentage (\%) \\
\hline Needs & 33 & 91,7 \\
No Need & 3 & 8,3 \\
\hline Total & $\mathbf{3 6}$ & $\mathbf{1 0 0}$
\end{tabular}

Source: Primary Data, 2021

Based on the table above, most of the respondents need an application for monitoring the growth and development of toddlers by 33 respondents $(91.7 \%)$.

\section{DISCUSSION}

In the results of this study, before the COVID-19 pandemic, monitoring of toddlers' growth was mostly carried out at Posyandu (69.4\%) and during the toddler's pandemic there was no monitoring of growth and development. Cadres visit door to door to find out the health of toddlers and provide PMT. Regular visits to Posyandu are influenced by the knowledge of mothers of children under five, the distance from home to Posyandu, and the number of children under five in the family (Sugiyarti et al., 2016). The results of the evaluation of toddlers' visits to the Posyandu during the pandemic, there was a decrease in public enthusiasm due to concerns about contracting Covid 19(Lahmadi et al., 2021).

The tools or instruments for assessing the growth and development of toddlers are mostly mothers who look at the Maternal and Child Health (KIA) book (55.6\%). The results of a study stated that mothers of toddlers already knew the contents and benefits of the Maternal and Child Health (KIA) book, but had not utilized the Maternal and Child Health (KIA) book optimally because the contents of the book were not up to date, not Under reality and the ease of obtaining it. information on growth and development via the internet (Lulianthy et al., 2020). The results of another study stated that knowledge of Maternal and Child Health (KIA) books were related to the quality of use of Maternal and Child Health (KIA) books (Sistiarani et al., 2014).

Monitoring the growth and development of toddlers during the Pandemic was not carried out because most of the mothers of children under five were unable to monitor independently (66.7\%), and the Posyandu was not yet running. The results of a study stated that during the Pandemic there was a decrease in the coverage of K1, K4, delivery coverage in health facilities and had a very influential impact on monitoring the growth and development of Toddlers (Yulia et al., 2021). In Styawati \& Ariany's research (2020), monitoring the growth and development of toddlers during the Covid 19 period by utilizing the development of mobile-based technology to make it easier for parents, Posyandu cadres, and Puskesmas in monitoring growth and development (Styawati \& Ariany, 2021). The research is in line with the needs expected by respondents in the form of applications for 


\section{Journal Of Nursing Practice}

http://thejnp.org

ISSN: 2614-3488 (print); 2614-3496 (online)

Vol.5 No.1. October 2021. Page.120-125

toddler growth and development that can be done independently $(91.7 \%)$.

\section{CONCLUSION}

Based on the survey, monitoring the growth and development of toddlers that are up to date and utilizing technological advances is very much needed by mothers of toddlers in monitoring the growth and development of toddlers during the Covid-19 pandemic.

ACKNOWLEDGMENTS (if any):

This research was funded internally from Universitas PGRI Adi Buana Surabaya through Adi Buana Competitive Grants for the 2020 fiscal year. Members in this study were Isabella hasiana with competency specifications for Master of Psychology and involved students in surveys and research implementation.

\section{CONFLICTS OF INTEREST}

In this study, there is no conflict of interest

\section{REFERENCES}

Amanullah, G. (2018). Analisis Perkembangan Anak Usia Dini Indonesia 2018-Integrasi Susenas dan Riskesdas 2018 (B. Santoso, D. Susilo, ida E. Harahap, siswi P. Astuti, \& B. A. Arsyad (eds.); Vol. 148). Badan Pusat Statistik.

Kemenkes. (2021). Laporan Kinerja Kementrian Kesehatan Tahun 2020. Kemenkes, 1-209. Kementerian Kesehatan Republik Indonesia. (2020). Panduan Kesehatan Balita Pada Masa Pandemi Covid-19. Kementrian Kesehatan RI, 1-30.

Lahmadi, L., Multazam, A. M., \& Kurnaesih, E. (2021). Evaluasi Kunjungan Balita Ke Posyandu Di Masa Pandemi COVID-19 Di Puskesmas Totikum Kab. Banggai Kepulauan. Journal of Muslim Community Health (JMCH), 2(3), 138-153.

Lulianthy, E., Setyonugroho, W., Mawarti, R., \& Permana, I. (2020). Pemanfaatan Buku KIA untuk Pemantauan. Proceeding Book Health National Conference, 6-11.

Sistiarani, C., Gamelia, E., \& Hariyadi, B. (2014). Analisis Kualitas Penggunaan Buku Kesehatan Ibu Anak. Jurnal Kesehatan Masyarakat, 10(1), 14-20. https://doi.org/10.15294/kemas.v10i1.3065

Styawati, S., \& Ariany, F. (2021). Sistem Monitoring Tumbuh Kembang Balita/Batita di Tengah Covid-19 Berbasis Mobile. Jurnal Informatika Universitas Pamulang, 5(4), 490. https://doi.org/10.32493/informatika.v5i4.7067

Sugiyarti, R., Aprilia, V., \& Suci Hati, F. (2016). Kepatuhan Kunjungan Posyandu dan Status Gizi Balita di Posyandu Karangbendo Banguntapan, Bantul, Yogyakarta. Jurnal $\begin{array}{llll}\text { Ners Dan } & \text { Kebidanan }\end{array}$ https://doi.org/10.21927/jnki.2014.2(3).141-146

UNICEF. (2020). COVID-19 dan Anak-Anak di Indonesia Agenda Tindakan untuk Mengatasi Tantangan Sosial Ekonomi. Journal of Education, Pshycology and Counseling, 2(April), 1-12. www.unicef.org

Widiastuti, A., \& Winarso, S. P. (2020). PROGRAM PMT DAN GRAFIK PERTUMBUHAN BALITA PADA MASA PANDEMI COVID. Analisis Kepuasan Ibu Bersalin Di Ruang Kebidanan, 2(1), 18-23.

Wulandari, H., \& Pangastuti, R. (2020). Pengembangan Aplikasi Kesehatan Berbasis Mobile Untuk Pemantauan Deteksi Dini Tumbuh Kembang (DDTK) Anak Usia 4-6 Tahun. Al-Athfaal: Jurnal Ilmiah Pendidikan Anak Usia Dini, 3(1), 98-111. https://doi.org/10.24042/ajipaud.v3i1.6912 


\section{Journal Of Nursing Practice}

http://thejnp.org

ISSN: 2614-3488 (print); 2614-3496 (online)

Vol.5 No.1. October 2021. Page.120-125

Yulia, R., Syafiq, A., Pratomo, H., \& Sulastri, N. E. (2021). DAMPAK PANDEMI COVID19 PADA LAYANAN KESEHATAN IBU DAN ANAK (KIA ) DI KOTA DEPOK THE IMPACT OF COVID-19 PANDEMIC ON MATERNAL AND CHILD HEALTH (MCH) SERVICES IN DEPOK CITY. 17(2). https://doi.org/10.19184/ikesma.v 